\title{
Analysis on the Bottlenecks in Development of Chinese Original Children's Picture Book Publishing and the Countermeasures
}

\author{
Jinyu Yang \\ Journal Editorial Department \\ Kunming University \\ Kunming, China 650214
}

\begin{abstract}
The murals appeared in caves in ancient times can be regarded as the prototype of picture book. Later, scroll paintings and comic strips and other forms appeared and gradually formed one of the most popular children's books in the current times. In recent years, the sales of children's picture books in China have soared and driven the development of book retail industry. Compared with mature and scaled picture book publishing market in Europe, America and Japan, China does not have branded picture book publishing house, and the original picture books lack market competitiveness. The development and innovation of Chinese original children's picture book may be boosted by drawing on excellent experience of foreign countries, broadening the material selection of picture books, enriching the expression method of paintings, and focusing on brand marketing and other paths.
\end{abstract}

Keywords—children's picture books; original picture books; picture book publishing; publishing status; publishing countermeasures

\section{INTRODUCTION}

"绘本" (picture book) is sourced from the Chinese character "绘本" in the Japanese version of picture book "えほ $h$ ". As the name implies, picture book is "painted book", a form of books that tells stories through painting. For children, especially for preschool children, picture book has its unique attraction. The beautiful and vivid pictures and simple and easy-to-understand text descriptions not only have the function of entertainment and relaxation, but also have unique educational significance. Therefore, picture books are very popular among parents and children in the market of children's books.

\section{THE ORIGIN AND History OF CHINESE PICTURE BOOKS}

As early as in primitive society, human had begun to leave special marks on caves, animal skins or bones. During the period of Northern Wei Dynasty, Chinese ancestors recorded many stories or biographies in form of murals by continuous painting on the walls. For example, Dunhuang murals in Mogao Grottoes vividly recorded the many stories such as "九色鹿本生 (Vessantara Jataka of Nine-color Deer)" and "阁肉贸鸽图 (Painting of Emperor Cutting His Meat in Exchange for the Dove)". Up to Wei and Jin Dynasties, the appearance of scroll paintings enriched the expressive power of story such as (Eastern Jin Dynasty) Gu Kaizhi's "洛神府图 卷 (Scroll Painting of Ode to the Goddess of the Luo River)" and "女史筬图卷 (The Admonitions Scroll)". On the scroll painting, different characters constitute a continuous storyline, there are simple textual descriptions attached besides the painting. This form is very similar to the later comic strips.

Later, with the introduction of Buddhism, believers used fine silk strips to spread Buddhism. Usually, each piece of fine silk strip was attached with pictures and captions. In a sense, it can be regarded as the prototype of comic strips. After Tang Dynasty, printing was widely used, and illustrated books appeared in large numbers. In the 20th year of Wanli period in Ming Dynasty, China appeared the earliest comic strip work "孔子圣迹图 (Painting of Life Stories of Confucius)" which was painted by Qiu Ying and described by Wen Zhengming of Ming Dynasty. In form of comic strips, this work presented the life traces and historical events of Confucius, such as "问礼老秧 (Consultation to Lao Tzu)"，"韦编三绝 (Study Diligently)"，"泰山问政 (Asking the People's Situation on Mount Taishan)", "诛少正印 (Killing Shaozheng Mao)", "夹谷会齐 (Meeting in Jiagu)", "楚狂接舆 (Madman Lu Jieyu of Chu State in the Spring and Autumn Period)", and other familiar stories. This comic strip has 105 pages; each page is attached with color pictures and text; each page is $60 \mathrm{~cm}$ long and about $40 \mathrm{~cm}$ wide, and is larger than the current 2A4-sized newspaper. In the social situation at that time, this kind of comic strip was provided to people with certain cultural knowledge for appreciation. This picture album is now preserved in the National Library of China. During the Ming and Qing Dynasties, a large number of line drawing illustrated books appeared. In front of the chapters of Zhanghuiti-style novels (a type of traditional Chinese novels divided into several chapters with each chapter headed by a couplet giving the gist of its contents), there were several story plot illustrations which were called "Huihui pictures" at that time.

In 1899, Shanghai Literature and Art Book Company published the lithographic version of "Full Pictures of the 
Romance of the Three Kingdoms" which was the first work to express the original contents of a literature work in form of comic strip. During the period of the Republic of China, comic strips developed rapidly. In addition to traditional classical literature and myths and legends, the subject of stage comedy also appeared. In the meantime, Zhang Leping's "三毛流浪记 (The Winter of There Hairs)" and Zhang Guangyu's "西游漫记 (Comic Journey to the West)" are masterpieces of China's comic strips, and can also be called pioneering works of local picture books.

After the founding of New China, because of the easy-tounderstand feature of comic strips, the government treated comic strips as an important way to educate people; consequently, comic strips were not only an extracurricular reading for young people, but also an important part of many adults' cultural entertainment. The major publishing works were undertaken by Beijing People's Publishing House and Shanghai People's Publishing House. Most picture books during this period applied folk art calligraphy, and was based on revolutionary historical events and the people's life and construction enthusiasms in the early stage of New China and in line with the view of values in the new society; in the meantime, a large number of outstanding Chinese painting masters such as Wang Shuhui and Liu Jiyou emerged. The works of famous artists improved the artistic level of comic strips. With the development of the society, there are more and more excellent works. For example, the "团圆 (Reunion)" as published jointly by $\mathrm{Yu}$ Liqiong and Zhu Chengliang in 2008 won the first "Feng Zikai Picture Book Award" in Hong Kong.

\section{StATUS QUO OF CHILDREN'S PICTURE BOOK PUBLISHING IN CHINA}

Since the beginning of the 21 st century, book publishing industry has faced new challenges and opportunities. Some giant publishers have been constantly adjusting their orientation and maintain in good overall development trend in book publishing industry under the stimulation of new media. Among them, children's books have made great contribution to the development of books. More than $30 \%$ of the growth in sales of book retailing comes from children's books, especially from children's picture books. In recent years, children's picture book market in China enjoys a very prosperous development, and picture book has occupied an important position in Chinese children's book market. Hundreds of publishing houses across China have seized the market opportunities and successively entered the field of children's picture book publishing. It was around 2010 that picture book became very popular in China. In 2014, more than 4,000 kinds of children's books were published and among them more than 4,000 kinds of children's books were picture books accounting for one tenth of the entire children's books publishing market. Among the picture books, about half of them were introduced from foreign countries and about half of them were originally created in China. In 2017, Chinese children's books accounted for $24.6 \%$ of the overall book retail market. Among them, picture books and comic strips accounted for $23 \%$ of the children's book retail market, ranked second and just inferior to literature books.
However, in this huge and growing market, there is in huge lack of domestic original contents. According to relevant survey data, in the entire children's retail market in 2017 , overseas works accounted for $41.03 \%$ by fixed price, and more than $30.6 \%$ by varieties. From the overall trend, the proportion of overseas children's books was increased from $34.61 \%$ in 2014 to $41.56 \%$ in 2016. Dangdang's annual report on the children's book market also shows the case: from 2013 to 2017, among the children's books sold by Dangdang in the 5 years, original works accounted for $1 / 3$ of the total sales, while introduced children's books accounted for $2 / 3$. The "salable picture books" had an annual sales volume reaching more than 15,000 sets / book, but there was not any set of original picture books created in Mainland China. Among the original works with annual output less than 100 kinds, rare of them were impressive. This is not just a dilemma faced by one or two publishing houses, but also the status quo that the entire children's book market wants to change.

As early as on September 15, 2011, the People's Daily published a report on the "Foreign Picture Books Monopolizes the Bestseller List of Online Children's Books". The report pointed out that picture book has become a popular children's book, but the weak original ability, the market monopolized by foreign picture books, and the cultivation of people's reading habits had become the real problems to be faced by picture books in China. Nowadays, those conditions have not yet been improved.

\section{BOTTLENECKS ENCOUNTERED IN THE DEVELOPMENT OF CHINESE ORIGINAL CHILDREN'S PICTURE BOOKS}

It was almost in the 17th century that picture books emerged in Europe and then flowed to the United States. In the 1950s and 1960s, picture books emerged in South Korea and Japan; then reading picture books also became popular in Taiwan. From then on, a fever of reading picture books was raised. Compared with the long history of picture books in western countries, China has not yet formed its unique picture book culture. With the increase of Chinese publishing houses and the holding of a large number of picture book promotion activities, Chinese families gradually began to attach importance to picture books in aspects of children's growth and interest cultivation.

\section{A. Limited Subjects for Creation of Original Picture Books}

As Yang Zhong, the director of picture book creation workroom of Central Academy of Fine Arts, said, "Picture book is like a small art museum, having a variety of expression forms such as watercolor painting, oil painting, and comics and so on, so that readers can have a great artistic visual experience". The soul of picture book is full of childishness and fun by exaggeration, metaphor, contrast, repetition and other expression methods. The rich language expression and the inherent contradictions and conflicts in the story make the picture book interesting and humorous so that children can experience happiness while reading it. Taking the masterpiece of Japanese picture book master Taro Gomi "The Crocodile and the Dentist" as an example, in the expression of colors, the picture book adopts distinct contrast 
in colors of clothes to present the dentist and the crocodile; the plain and repeated language subtly renders the mutual fear psychology of the crocodile and the dentist. The ferocious crocodile appears childish awkward, while the timid dentist appears calm and brave; this contrast between images of the characters can make children laugh; the story is funny and ironic and also enriches the significance of life education, reminding children the importance of protecting their teeth. Similar comic books also include "母鸡萝丝去散步 (Rosie's Walk)", "要是你给老鼠吃饼干 (If you give a mouse a cookie)", "妞妞的鹿角 (Imogene's Antlers)", "子儿, 吐吐 (Spit the Seeds)" and so on.

"Love" is the eternal theme of picture book. The first category is self-love, namely the self-centered love, and the second category is transcendental love, namely otherscentered love, abandoned self and without desire and fame and wealth pursuit. The theme of children's literature works is generally transcendental love "others-centered love". Such thematic expression forms include parents' love for their children, such as "月下看猫头鹰 (Owl Moon)", "猜猜我有多爱你 (Guess How Much I Love You)" and "睡不着吗小熊 (Little Bear Can't You Sleep?)", grandparents' love for grandson, such as "爷爷一定有办法 (Grandpa Must Have A Way)" and " 爷爷的天使(Grandpa's Angel)", plain love-themed works such as "黑兔和白兔 (Black \& White Rabbit)" and "活了一百万次的 猫 (The Cat Who Lived a Million Times)", as well as universal love-themed works such as "你不能带气球进大都会博 物馆 (You Can't Take a Balloon into the Metropolitan Museum)" and "会飞的抱抱 (The Giant Hug)".

China has a long history. Traditional culture is the main source for creation of children's picture books. In some original picture books, Chinese history and traditional culture are expressed in the form of extremely classical aesthetics and oriental artistic sense, bringing different aesthetic experience in reading. On the market, the subjects of Chinese children's original picture books can be divided into: folk stories, classic books and celebrity stories. The main representative works are: Xiong Liang's "京剧猫 (Beijing Opera Cats)", "灶王爷 (The Kitchen God)", "石狮 (Stone Lion)", "好玩的汉字 (Interesting Chinese Characters)" and "年 (Nian: the New Year Monster)", and Bao Dongni's "虎妞妞 (Hu Niu Niu)", "神奇虎头帽(Magic Tiger Head Cap)", "北京记 忆：小时候的故事 (Beijing Memory: Childhood Stories)", and "小小虎头鞋 (Little Tiger Head Shoes)" and so on. However, the numbers of sales and comments of those picture books are not high. Publishing unit also just makes repeated exploration and creation on the basis of traditional culture, ignoring reader's reading interest. As a result, readers' reading interest is reduced due to the similar content and ideas in the book. Some of them just imitate the picture books of Japan and Europe and the United States for the purpose of introduction. The creation subjects are monotonous and concentrated and fail to fully present and explore the life, psychological and status of children. Therefore, original picture books still need to make efforts in aspect of conception, drawing and text flexibility.

\section{B. Insufficient Talents for Children's Picture Book Publishing}

Tadashi Matsui is a member of the Japan Publishing Society and also a world-renowned influential master of picture books. His understanding, practice and dissemination of books have influenced generations until today. He believes that it is necessary to firstly attach importance to children's happy feelings when reading picture books; picture book has not any "use" for young children; it is not for learning things, but for feeling happiness; picture book is neither textbook, nor even a collection of problem solutions but a source of children's happiness so that children can feel that reading is a kind of enjoyment. The market of picture books in Europe, America and Japan fully considers the age and psychological characteristics of children of different ages, pays attention to market segmentation and readers tastes, and creates different levels picture books from different aspects such as life education, inspiring mind, experience growth, courage and confidence. Their picture books are in line with the current life, comply with children's cognitive level and psychological laws, can stimulate readers' interest in learning, and inspire their thinking from reader's perspective and are thus loved by children.

From the perspective of the target market, Chinese original picture books do not have detailed division on readers; readers of picture books are monotonous; meanwhile, picture book pays attention to learning of knowledge, getting knowledge incorporated into its creation, for the purpose of imparting knowledge, pays more attention to nationalization, and is not close to real life and reader's cognitive level. There is a certain gap between picture book and reader's cognitive level and understanding ability. As far as style is concerned, taking the prize-winning works of Feng Zikai as an example, the expression technique of the picture book is either line drawing or sketching to show the shape of things and highlight the characteristics; most of his works depict the beauty in artistic conception of things. The contents of his works are mainly pictures, attached with text merely for explaining the pictures so that the pictures look slight stiff. The picture books in Europe and America pay attention to the integrity of pictures, use modern materials, rich and warm colors, and more emphasis on improving reader's aesthetic ability; the overall layout is reasonable, and the paintings are integrated into one. Hence, how to get pictures well combined with text becomes the bottleneck in creation of original picture books. In China, there are lack of influential well-known writers and painters, and even rare excellent picture book painters. Yang Zhong said that his studio has recruited six periods of students with total number exceeding a hundred students; but when they graduated, most of them engaged in illustrations, design, etc., and few of them can publish picture books. Cao Wenxuan is the only writer in China who has won the International Andersen Award. When visiting in Beijing in August 2014, Tadashi Matsui also pointed out the way for Chinese picture books: "Chinese art is very great. I hope that you do not simply imitate that in Europe and the United States, but fully use and play your own traditions to create it and convey it to future generations". He also said, "Painters should not pay attention to how good their paintings are but attach 
importance to telling a good story by those paintings. At the same time, a good story can make people imagine the world of the story while listening to it".

\section{Incomplete Publishing System and Insufficient Marketing Experience}

China's existing publishing system is also one of the constraints that affect the development of China's original picture books. Under the stimulation of the market economy, publishing house is oriented to make profit; how to maximize the profit in the shortest cycle becomes the goal pursued by many publishing houses. However, a good picture book often takes at least a year or more time to create. The market situation of original picture books in the past few years has made publishers less confident in original picture books, and turned their attention to mature foreign picture book market. If only the copyright is obtained, they would be accessed to introduce original picture books from foreign countries. In this way, they can obtain higher benefit and return by doing little work. The book industry's support for original picture books was originally small; if lacking the support of publishers, author's creative passion would be more affected. China's picture book market is basically separated, with disorderly competition and weak marketing programs; branded publishing houses have not yet appeared. Whereas in Europe, America and Japan where there are relatively mature market of picture books, professional branded publishing houses have appeared and are relatively concentrated. For example, the ふくいんかんしょてん (福音馆) in Japan has a history of more than 50 years. It is famous in the internal publishing industry for publishing picture books and has occupied the leading position in Japanese picture book market.

\section{COUNTERMEASURES FOR DEVELOPMENT AND INNOVATION OF CHINESE ORIGINAL CHILDREN'S PICTURE BOOKS}

\section{A. Seeking Diverse Subjects for Picture Books}

Drawing on the experience of other countries, it is not difficult to find that the picture book market in America is relatively mature and the subjects are also rich and diverse, such as conveying the mainstream values and spirit of the country or making discussion on philosophy and history or making bold conception and creation on the future world by virtue of picture books. Those aspects are worthy of careful study and reference by Chinese publishers and writers. Only if picture book is created from the perspective of children can it really play the role of providing education in amusement. The subjects selected for Chinese original picture books should not only be close to life, maintain Chinese characteristics, but also conform to the trend and development of the times, in line with the current readers' cognitive level and mental laws. For example, classic masterpieces, historical stories, ancient poetry, idiom stories, scientific and technological achievements, family life, natural scenery, human geography and so on can all be used as the subjects of picture books. Picture books should not be for the purpose of imparting knowledge, but get ideology and culture mixed in the picture book in a subtle way to give children a happy reading experience while unconsciously acquiring more knowledge and broadening their vision. It is not only needed to expand the subjects, but also needed to make innovation in forms, explore a way and path of development integrated children's aesthetic demand and children's stories. When creating picture books, it is necessary to take into consideration children's understanding ability and acceptability rather than merely highlighting the interesting nature; the way of only attracting children by pictures cannot last long. Over-emphasizing the function or highlighting the educational goals of classroom and ignoring the fun of picture book is another flaw in the current original picture books. The exquisite nature of picture book lies in the matching and combination of graphics and text, as well as the imagination and creativity conveyed in the picture book. At present, most human history themed picture books on the market combine with some knowledge points of current school education. Although enjoying highly respect by parents, those picture book have lost the original intention so that children cannot feel the beauty of the picture book in reading. It is not conducive to when reading. The beauty of the picture book is not conducive to children's aesthetic formation.

\section{B. Dividing Readers' Ages in Detail and Creating Picture Books Suitable for Specific Age Groups of Readers}

Children's publishing houses should carefully study the psychological and age characteristics and demands of children in different age groups. Currently in China, primary school time is generally used as the dividing line that divides children's picture books into preschool picture books and kids' picture books. Kids' picture book is actually just a general concept and should be subdivided. At different ages, children's language competence, behavior, intelligence, and preferences are different. Publishers and writers should develop different picture books for different age groups of children through careful research. However at present, some children-oriented picture books are lack of experiences in setting of picture and font sizes and text difficulty and appear incompliance between text and pictures so that children's reading interests are affected and the books fail to play the applicable role of enlightenment and education.

\section{Cultivating Excellent Original Picture Book Writers and Painters}

Picture is the vitality of a picture book. As a children's book editor said in an interview, "Because picture book has the function of aesthetic education, firstly the picture and book binding should have good appearance and collection value; secondly, the story should be attractive, novel and childlike... When selecting picture books, people would first consider whether the story is told well and suitable for children, and then consider the picture quality, the value and exploration significance of the subject and the potential of the marketing point, as well as acceptability of this type of picture books on the market and the sales of the competitive products; meanwhile, they may also take into account the author's award-winning status". Literature works are different from film and television works as the former is to 
convey information by words; hence, it is necessary to select story suitable for children and express the story in appropriate method. Besides, it is necessary to maintain the harmony and unity between pictures and words, and get them closely combined with each other. The status quo of original picture books in China is lack of writers who can tell stories very well and lack of souled illustrators. China has plenty of outstanding writers. A large number of outstanding children's book writers have emerged since the founding of New China. However, it is worthwhile for all writers to make joint exploration and for all Chinese to make joint efforts on how to express a story in a vivid and concise language provided that the original interesting taste of the story is not reduced. Everyone is possible to become the "raconteur". Traditional Chinese paintings are good at expressing landscapes, figures, flowers and birds by using figurative and freehand brushwork and have extremely oriental characteristics; if traditional Chinese paintings are integrated into picture books, it will be possible to greatly enhance the competitiveness of original picture books in China.

\section{Improving the Comprehensive Competitiveness of Children's Book Publishing Houses}

Chinese children's book publishing houses should "go out" and constantly learn from and absorb the advanced experience of well-known foreign publishing houses to make up their own shortcomings. First of all, it is necessary to make reform and innovation inside the publishing house to stimulate the vitality of the enterprise and truly become market-oriented. Secondly, through cooperation with excellent picture book publishing houses, it is conducive to re-examining children's book publishing from international vision, creating exquisite picture books, posing brand effect, enhancing the influence of its picture books and further building it into branded publishing house. Finally, in terms of talent cultivation, publishing house should change the old way of thinking and enhance the enthusiasm and mission of writers by setting up awards, developing outstanding works evaluation and exhibition activities and giving excellent painters, publishers and writers applicable awards.

\section{CONCLUSION}

Over thousands of years of historical precipitation, Chinese civilization has become a shining pearl in the Eastern culture; no matter the creation myth in ancient times, the allegories blended education into entertainment, the fearless and brave Sun Wukong, or the weak Lin Daiyu, they have all went deep into the bone marrow of every Chinese people and are worthy of being passed down by generations of Chinese. Picture book is also a way of civilization inheritance and cultural preservation. Through beautiful pictures and exquisite text, those traditional cultures with distinct Chinese characteristics can be carried forward to nourish every inch of cells of every child and get the beautiful seeds rooted and blossoming in the deep soul of children.

\section{REFERENCES}

[1] Li Yingqing, Tan Xudong. On the Development Course of Japanese Picture Books [J]. China Publishing Journal, 2010(11):62-64. (in Chinese)

[2] Tan Xudong. The Development Track and the Creation Ways of the Contemporary Children Literature $[\mathrm{J}]$. Journal of Xianyang Normal University, 2009(3):84-88. (in Chinese)

[3] Wu Meizhen, Tan Xudong. The development of the children's literature during the 30-year reform and opening-up in China [J]. Jianghuai Tribune, 2008(6):170-173. (in Chinese)

[4] Luo Wushuang. A Comparative Study of Chinese and American Children's Science Picture Books [D]. Journal of Harbin Normal University, 2010. (in Chinese)

[5] Tan Xudong. The past, present and future of Chinese picture books [J]. China Education Daily, 2013 (10): 1-3. (in Chinese)

[6] Bian Xiaoxuan, Yang Xu. Chinese picture book just starts on the line [N]. People's Daily, 2011-09-15. (in Chinese)

[7] Pan Mingge. Analysis on the Development Path of Chinese Original Children's Picture Books [J]. Academic Corner, 2016(18): 32-35. (in Chinese) 